\title{
Impact of Bush Encroachment on Livestock Production and Pastoral Livelihoods in Fentale District, Eastern Ethiopia
}

\author{
Sisay Kebede ${ }^{1}$, Zewdu K. Tessema ${ }^{2}$, Mengistu Urge ${ }^{3}$, Mehari Alebachew ${ }^{4} \&$ Abule Ebro $^{5}$ \\ ${ }^{1}$ School of Animal Sciences, Debre Berhan University, P.O. Box 445, Debre Berhan, Ethiopia \\ ${ }^{2}$ College of Agriculture and Environmental Sciences, Debark University, P.O. Box 140, Debark, Ethiopia \\ ${ }^{3}$ School of Animal and Range Sciences, Haramaya University, P.O. Box 138, Dire Dawa, Ethiopia \\ ${ }^{4}$ Ethiopian Environment and Forest Research Institute, P.O. Box 2003, Addis Ababa, Ethiopia \\ ${ }^{5}$ Wageningen University and Research, BRIDGE project, P.O. Box 49675, Addis Ababa, Ethiopia \\ Correspondence: Sisay Kebede, School of Animal Sciences, Debre Berhan University, P.O. Box 445, Debre \\ Berhan, Ethiopia. E-mail: sisayk@ymail.com
}

Received: September 3, 2020 Accepted: September 23, 2020 Online Published: October 29, 2020

doi:10.5539/sar.v9n4p56 URL: https://doi.org/10.5539/sar.v9n4p56

\begin{abstract}
The threat of bush encroachment on community livelihoods and economy in range lands of Fentale district in Ethiopia is not well known. So, this study was conducted to evaluate the impact of bush encroachment and its stress on livestock daily milk yield and pastoral livestock production of the district. The data of household livestock holding and its production, household income sources, expenditure, etc. was obtained from district pastoral and agro-pastoral office and the respective pastoral communities. The data was collected through semi-structured questionnaires, focus group discussion and key informant interviews. The data was analyzed through descriptive statistics and regression analysis using Minitab Software. The result revealed that there was an alarming rate increasing of bush encroachment coverage and positive association $(\mathrm{P}<0.05)$ with camel and goat population than cattle and sheep population $(\mathrm{P}>0.05)$ in the study district. Results of current study also revealed that a positive correlation between increasing coverage of bush encroachment and mean daily milk yield of livestock (i.e. cattle, goat and camel) in the study areas. Pastoral producers also perceived the impact of bush encroachment on livestock population trend and milk production in all study sites and applied different adaptation strategies (like feed supplementation and mobility). It is recommended that appropriate intervention options (like bush thinning) of government and other stakeholders is needed to alleviate the current economic bush related challenges of pastoral producers and save the loosing natural resources, even by amendment of pastoral production related policies and its implementation
\end{abstract}

Keywords: coverage, livelihoods, milk yield, pastoral, population

\section{List of abbreviations}

CSA: Central Statistical Agency

EARO: Ethiopian Agricultural Research Organization

\section{GDP: Gross Domestic Product}

\section{HH: Household}

IFPRI: International Food Policy Research Institute

ILRI: International Livestock Research Institute

IRIN: Integrated Regional Information Networks

L: Liter

M.A.S.L.: meter above sea level

SPSS: Statistical Package for Social Science

USA: United States of America 


\section{Introduction}

Rangelands are the major source of forage for grazing animal which used to provide agricultural products such as wool, meat and milk. Increases in the density of woody plants and the suppression of herbaceous plants (i.e. palatable grass species) threatening livestock grazing and wildlife production systems in the world. Rangelands further provide habitat for wildlife, however, have an impact on the economy through activities that make use of them (Julia et al., 2007). Therefore, in order to realize the impact of encroachment on rangelands, it is important to understand the total economic loss through agricultural and non-agricultural products of the ecosystems (Julia et al., 2007).

Extensive pastoralism occurs on one fourth of the global land area and supports around 200 million pastoral households (Nori et al., 2005) and in Africa, $40 \%$ of the land is dedicated to pastoralism (Integrated Regional Information Networks [IRIN], 2007). Livestock production is one of economic activity widely practiced in these areas (Randolph et al., 2007; Cecchi et al., 2010). In sub-Saharan Africa alone, 25 million pastoralists and 240 million agro-pastoralists depend on livestock (International Food Policy Research Institute [IFPRI] and International Livestock Research Institute [ILRI], 2000). The rapid expansion of encroachment and invasion of woody plant species in Ethiopia has been widely reported as a common form of rangeland degradation (Ayana and Oba, 2008). However Prosopis julifolora, Accacia seyal, Accacia melifera and Accacia senegal are of a major concern (Amaha, 2006). Especially, the spatial extension of Prosopis juliflora in Ethiopia is even difficult to assess since it is expanding rapidly, up to $18 \%$ per year (Felker, 2008). One million ha is already covered by Prosopis juliflora in entire Ethiopia (Ryan, 2011), of which about 700,000 ha are located in the Afar Region (Mueller et al., 2010). Some identified commonly disappearing herbaceous plant species in the study areas are Cenchrus ciliaris, Chloris virgata, Chrysopogon plumulosus, Cynodon aethiopicus, Cynodon dactylon, Ricinus communis and Acalypha indica. Economic impacts of bush encroachment may be related to a decline in cattle carrying capacity, wildlife carrying capacity and watershed quality due to its suppression of palatable herbaceous production in the range land. Reductions in cattle grazing due to expansion of bush coverage account for the direct agricultural costs (Julia et al., 2007). Later studies also indicate large damage costs as related to GDP; up to $12 \%$ in USA (Gren et al., 2009). Even though, many studies have conducted on range lands of Ethiopia, there are no accurate data on economic impact of bush encroachment on the areas of threaten by woody plant species for Afar and Somali regions by comparing of both encroached and non-encroached areas. Similarly, the threat of bush encroachment on community livelihoods and economy in range lands of Fentale district and other parts of the region is not well known. However, little has been done to assess the impact of bush encroachment on livestock population trend, animal milk production, community livelihood and economics in pastoral areas of Ethiopia. As a result, the communities' livelihood and economy as well as the environment are highly altered. Therefore, this study aimed to establish the economic impacts of bush encroachment on livestock production and household livelihoods in Fentale district of Eastern Ethiopia.

\section{Materials and Methods}

\subsection{Descriptions of the Study Area}

The study was conducted in Awash Fentale District, Afar Region, Ethiopia. The aforementioned site is located between $9^{\circ} 20^{\prime} \mathrm{N}, 40^{\circ} 20^{\prime} \mathrm{E}$, and at an altitude ranges from 740 to 1820 m.a.s.l. (Abule et al., 2005). The land coverage of the study district is estimated to be about 180,000 ha. According to CSA of the district, the human population was estimated to 29,780 , while the livestock population of the district was estimated to 45,060 cattle, 69,428 sheep, 123,702 goats, 33,129 camels, 4273 (donkey and horse) and 4346 poultry. Rainfall mostly occurs between July and September. In the district temperature varied from $21^{\circ} \mathrm{c}$ to $38^{\circ} \mathrm{c}$ with annual precipitation ranges from $450 \mathrm{~mm}$ to $500 \mathrm{~mm}$. The district is characterized by its $80 \%$ undulated and $20 \%$ plain landscape and soil type of loamy, clay and sandy nature. In the district ecological stages are facing bush encroachment, following disturbance by woody plant species which drive out more nutritive grazing and browsing vegetation (Piguet, 2001). Currently the districts' grazing land was facing high disturbances, by different encroaching woody species and known by its high bush coverage in the region. 


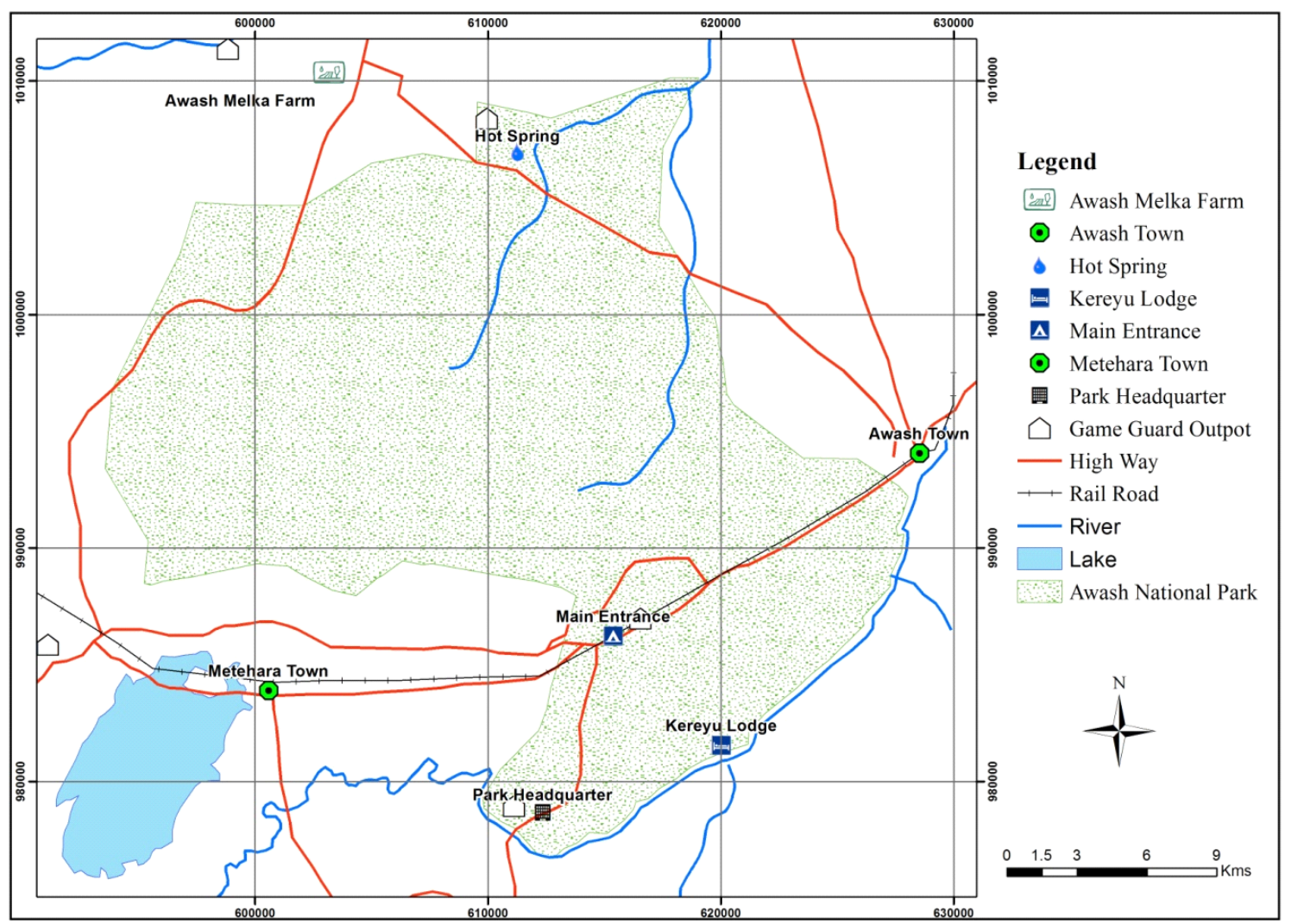

Figure 1. Geographical location of the Awash Fentale district with respect to Awash National Park, Methehara and Awash Melka town (Source: Biru et al., 2017)

\subsection{Sample Selection}

The Awash Fentale district was purposively selected due to its high bush coverage in the study region. Similarly, two kebeles were purposively selected based on their degree of bush encroachment. The first study kebele (i.e. Kebena) was purposively selected based on its high bush encroachment coverage and the second (i.e. Sabore) was selected based on its low coverage in the area. Then sixty pastoral households were surveyed based on their livestock production experiences of more than 30 years in the area. These were purposively divided into two categories depending on bush coverage. The first group were thirty households from Kebena kebele, where more than about $50 \%$ of the grazing land covered and the second were thirty households from Sabore kebele, where less than about $20 \%$ of the grazing land covered by bushes, according to the information source of Fentale district agricultural office.

\subsection{Survey Design and Data Collection}

Both primary and secondary data were collected. Primary data were collected through questionnaires and field observations. The primary data were collected from the 60 pastoral households using structured questionnaires. After pre-testing the questionnaire, the field data collection was administered by interview method. During the field data collection, information with related to feed and medicine related costs; pastoralists' bush encroachment perception; farm production, farm income expenditure, sell price and the like were assessed in the study district. Qualitative data such as household family size, educational status, sex, age and the like were also collected. Livestock population, average daily early milk yield of cow, goat and camel, were also collected through interview from the pastoralist households, key informant interviews and focus group discussions. Key informant interviews was done with different experts of the area, some non-governmental organization workers and both district and zonal agricultural office administration. Two focus group discussions containing of 10 members were held during field data collection. The secondary data with related to livestock population trend, areas bush coverage, impact of bush encroachment in the area, pastoral producers livelihood option and the like was taken from the study district. The focal groups included local elders, pastoralist associations, developmental workers and other experts and local administrations. The field data were collected during wet season from October to December, 2019. A 
structured check list was also developed, pre-tested and administered through interview method usinglocal language.

\subsection{Methods of Data Analysis and Interpretation}

The data were analyzed using Statistical Package for Social Science (SPSS), version 20. The software was used to describe and calculate some information like livestock daily milk yield, household total milk produce, household income and the like by using descriptive statistics. The associations between livestock population, milk production trend, livelihood and total revenue and total cost of production with estimated bush encroachment coverage in the study district was also determined by regression analysis using Minitab Software (Ver. 19.1).

\section{Results}

\subsection{Impact of Bush Encroachment on Milk Production Trend}

The bush encroachment coverage on the study district was found to be $50 \%$ for (Kebena) site and up to $20 \%$ for (Sabore) site based on the information obtained from the study district. Results of the regression analysis revealed that a positive correlation was obtained between herbage yield and mean daily milk yield (Table 1). Milk yields differed $(\mathrm{P}<0.05)$ between high and low encroached areas. The mean milk yield on highly encroached site (Kebena) was 5.5 $\mathrm{L}$ household ${ }^{-1}$ day $^{-1}$ while on low encroached site (Sabore) was about $6.8 \mathrm{~L}$ household ${ }^{-1}$ day $^{-1}$. Similarly, the current mean milk yield at (Kebena) site was much lower than the milk yield estimated (before 30 years) i.e. 14.3 $\mathrm{L}_{\text {household }}{ }^{-1}$ day $^{-1}$ (Figure 2).

Table 1. Household milk production per day in the study district (Total respondents $=90$ )

\begin{tabular}{lllllll}
\hline Variable & Min & Max & Mean & SD & Adj.R $^{2}$ & Pv \\
\hline Kebena & & & & & & \\
Milk Produced (L/day)-Cow & 1 & 3 & 2.07 & 0.593 & & \\
-Goat & 0 & 1 & 0.17 & 0.335 & & \\
-Camel & 0 & 7 & 3.22 & 1.677 & & \\
Total milk produced Current & 1.5 & 10 & 5.47 & 1.945 & $13.83 \%$ & 0.024 \\
Total milk produced before 30yrs & 8 & 20 & 14.28 & 2.698 & & \\
Sabore & & & & & & \\
Milk Produced (L/day)-Cow & 1.5 & 5 & 3.62 & 0.887 & & \\
-Goat & 0 & 1 & 0.46 & 0.474 & & \\
-Camel & 0 & 6 & 2.73 & 1.471 & & \\
Total milk produced Current & 4 & 10 & 6.80 & 2.045 & $51.95 \%$ & $\mathbf{0 . 0 0 0}$ \\
Total milk produced before 30yrs & 8 & 18 & 11.87 & 2.501 & & \\
mum; Max= Maximum; SD= Standard deviation; Adj.R ${ }^{2}=\mathrm{R}-\mathrm{sq}(\operatorname{adj}) ; \mathrm{P}=\mathrm{P}-\mathrm{value}$ &
\end{tabular}

Min $=$ Minimum; Max= Maximum; $\mathrm{SD}=$ Standard deviation; Adj. $\mathrm{R}^{2}=\mathrm{R}-\mathrm{sq}(\operatorname{adj}) ; \mathrm{P}=\mathrm{P}-\mathrm{value}$

The highest current milk yield $10 \mathrm{~L}_{\text {household }}{ }^{-1} \mathrm{day}^{-1}$, was obtained on highly encroached site while the lowest was $1.5 \mathrm{~L}_{\text {household }}^{-1}$ day $^{-1}$. So, the study results revealed that the mean milk yield obtained for low bush encroached sites was significantly different from that of high encroached sites (Figure 2). 


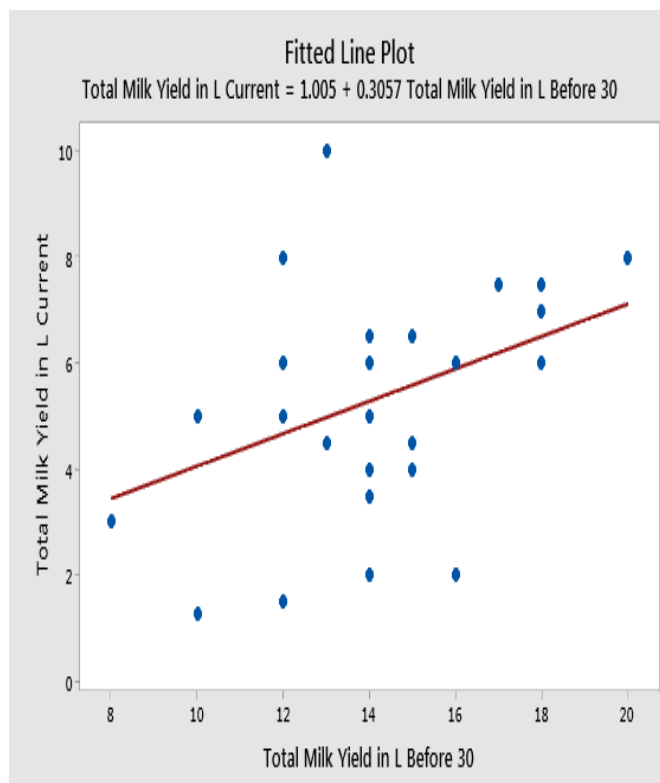

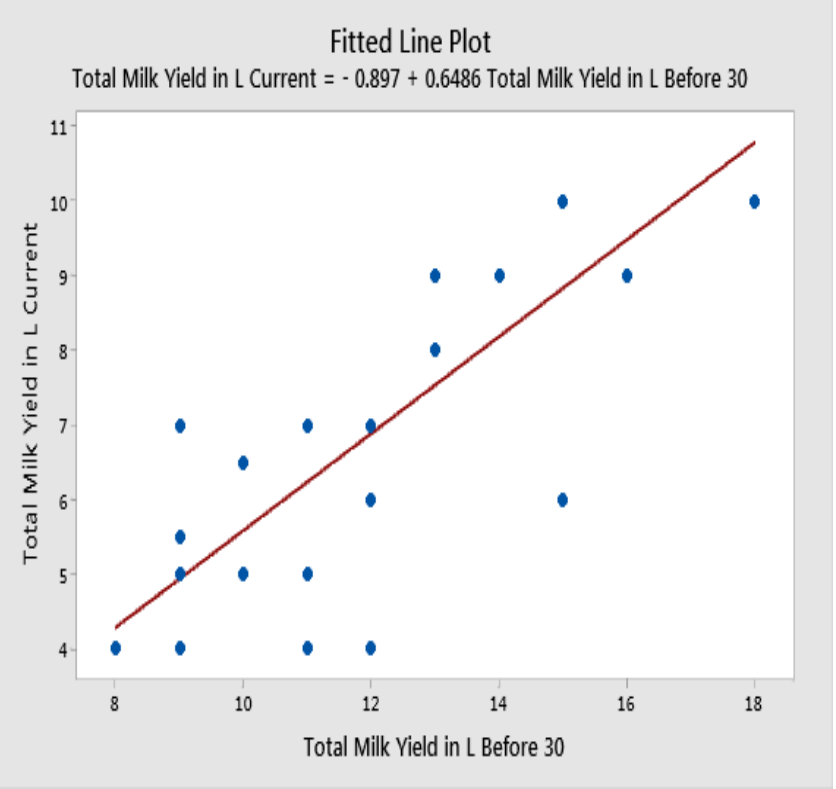

b

Figure 2. (a) Regression between Trends of milk yield per household (a) for Kebena site ( $P=0.024)$ and (b) for Sabore site $(\mathrm{P}=0.000)$ in Awash Fentale district

\subsection{Impact of Bush Encroachment on Pastoral Livelihood}

The mean annual income of pastoralist producers per Households from livestock and milk sales in Kebena and Sabore study sites were estimated to be about 34, 089 and 39, 606 Birr, respectively (Table 2). Similarly, the mean annual costs of pastoral producers to buy livestock feed and medicine was Birr 8189 in Kebena, which is much higher than the Birr 1670 in Sabore.

Table 2. Household total income and costs per annum in the study district.

\begin{tabular}{lllllll}
\hline Variable & Min & Max & Mean & SD & Adj.R & Pv \\
\hline Kebena & & & & & & \\
Average Total Income (Livestock and Milk sell) & 16560 & 45120 & 34089.66 & 6854.376 & $17.71 \%$ & $\mathbf{0 . 0 1 2}$ \\
$\begin{array}{l}\text { Average Total Cost (Feed and Vet.) } \\
\text { Average Milk Price }\end{array}$ & 4000 & 11600 & 8189.66 & 2184.089 & & \\
$\begin{array}{l}\text { Sabore } \\
\text { Average Total Income (Livestock and Milk sell) }\end{array}$ & $\mathbf{2 1}$ & & & & & \\
$\begin{array}{l}\text { Average Total Cost (Feed and Vet.) } \\
\text { Average Milk Price (Birr) }\end{array}$ & 0.00 & 53000 & 3900 & 1670.00 & 1025.923 & \\
\hline
\end{tabular}

Min= Minimum; Max $=$ Maximum; $\mathrm{SD}=$ Standard deviation; $\mathrm{P}=\mathrm{P}-\mathrm{value}$

Figures 3 show mean annual revenue and costs of livestock and milk product for Kebena and Sabore study sites respectively. The study affirmed that an increase in bush encroachment coverage in Kebena site significantly decreased pastoral producers annual income $(\mathrm{P}<0.012)$ (Figure 3). The highest income was 45, 120 Birr household $^{-1}$ annum ${ }^{-1}$, while the lowest was 16,560 Birr household $^{-1}$ annum ${ }^{-1}$. The highest income obtained for low encroached site was 53, 000 Birr household $^{-1}$ annum $^{-1}$, while the lowest was 20, 800 Birr household $^{-1}$ annum $^{-1}$. So, the study results indicated that the mean annual income obtained for low bush encroached sites was significantly higher than that of high encroached sites (Figure 3). 


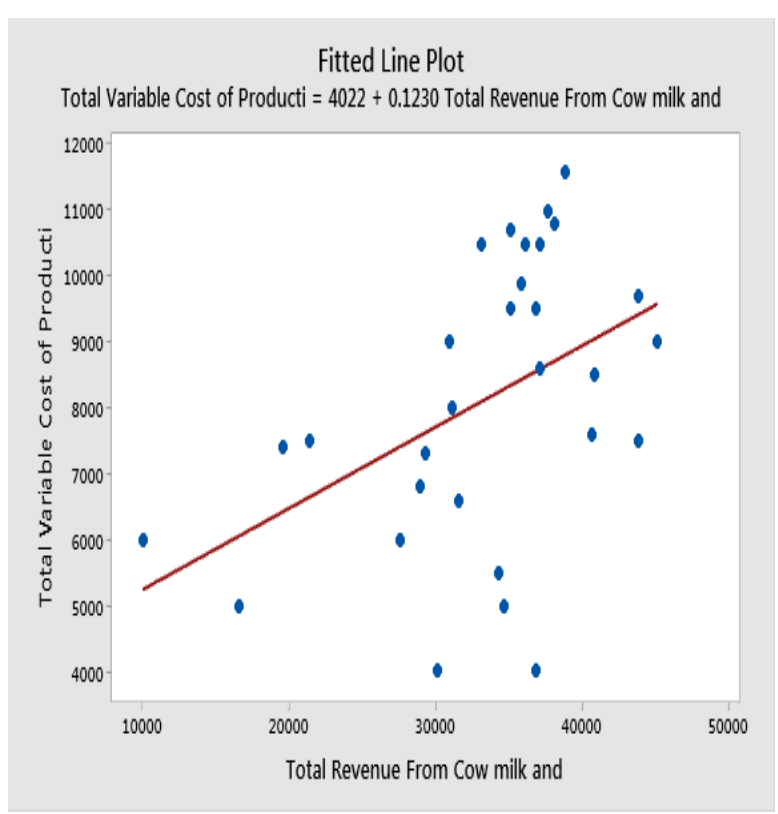

a

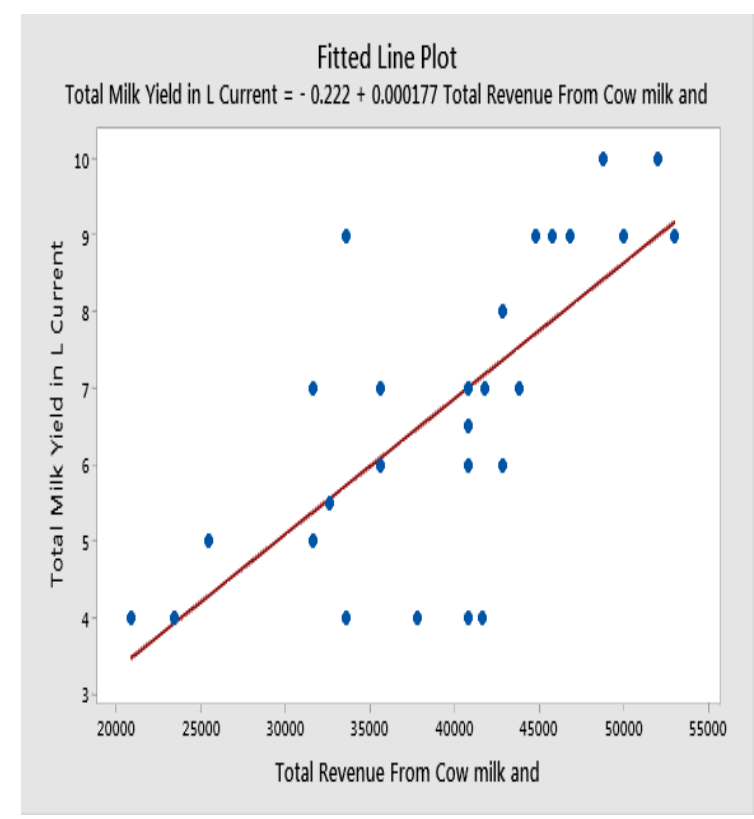

$\mathrm{b}$

Figure 3. (a) Regression between Mean Annual Income to Costs per household (a) for Kebena site ( $\mathrm{P}=0.012)$ and (b) for Sabore site $(\mathrm{P}=0.000)$ in Awash Fentale district

\subsection{Impact of Bush Encroachment on Livestock Population Trend}

In the study district, the former savannah grass land was shrinking, due to highly increasing rate of encroaching woody (i.e., accacia, prosopis, etc) and other herbaceous plant species. This results for lower herbage production per hectare in the study district. So, the mean of grazer livestock (i.e. cattle and sheep) was highly decreased with increasing bush encroachment coverage $(\mathrm{P}>0.05)$ in Kebena site (Table 3). Accordingly, pastoral producers in all study sites perceived a decrease in grazer livestock population with increasing coverage of bush encroachment for the last 30 years (Table 3 ).

Table 3. Trend of livestock population per household in the study district

\begin{tabular}{lllllll}
\hline Variable & Min & Max & Mean & SD & Adj.R $^{2}$ & Pv \\
\hline Sabore & & & & & & \\
Cattle population before 30yrs /HH & 14 & 70 & 29.83 & 11.486 & & \\
Cattle population current & 8 & 28 & 16.21 & 4.586 & $2.06 \%$ & 0.215 \\
Sheep population before 30yrs & 24 & 65 & 38.83 & 11.213 & & \\
Sheep population current & 0 & 32 & 13.00 & 11.557 & $20.63 \%$ & 0.007 \\
Camel population before 30yrs & 5 & 18 & 11.04 & 3.246 & & \\
Camel population current & 11 & 27 & 18.04 & 4.799 & & \\
Goat population before 30yrs & 13 & 75 & 31.41 & 12.780 & & \\
Goat population current & 21 & 54 & 39.38 & 9.002 & & \\
Kebena & & & & & & \\
Cattle population before 30yrs & 24 & 50 & 31.10 & 6.019 & & \\
Cattle population current & 5 & 27 & 15.90 & 5.511 & & \\
Sheep population before 30yrs & 24 & 63 & 39.83 & 10.869 & & \\
Sheep population current & 0 & 19 & 4.20 & 7.170 & & \\
Camel population before 30yrs & 7 & 23 & 12.43 & 4.327 & & \\
Camel population current & 12 & 34 & 21.23 & 6.719 & $73.15 \%$ & 0.000 \\
Goat population before 30yrs & 18 & 54 & 33.70 & 9.802 & & \\
Goat population current & 30 & 67 & 45.17 & 8.424 & $87.09 \%$ & 0.000 \\
\hline
\end{tabular}

$\mathrm{HH}=$ Household; Min= Minimum; Max= Maximum; $\mathrm{SD}=$ Standard deviation; $\mathrm{P}=\mathrm{P}$-value 
Based on these study results, cattle population was significantly decreased $(\mathrm{P}>0.05)$ with increasing bush encroachment coverage in all sites of the study district (Figure 4). Similarly, sheep population was also significantly lower $(\mathrm{P}>0.05)$ with increasing bush encroachment coverage in Kebena site than Sabore (Table 3). However, both cattle and sheep population were not significantly related $(\mathrm{P}>0.05)$ to the increasing bush encroachment coverage (Figures 4).

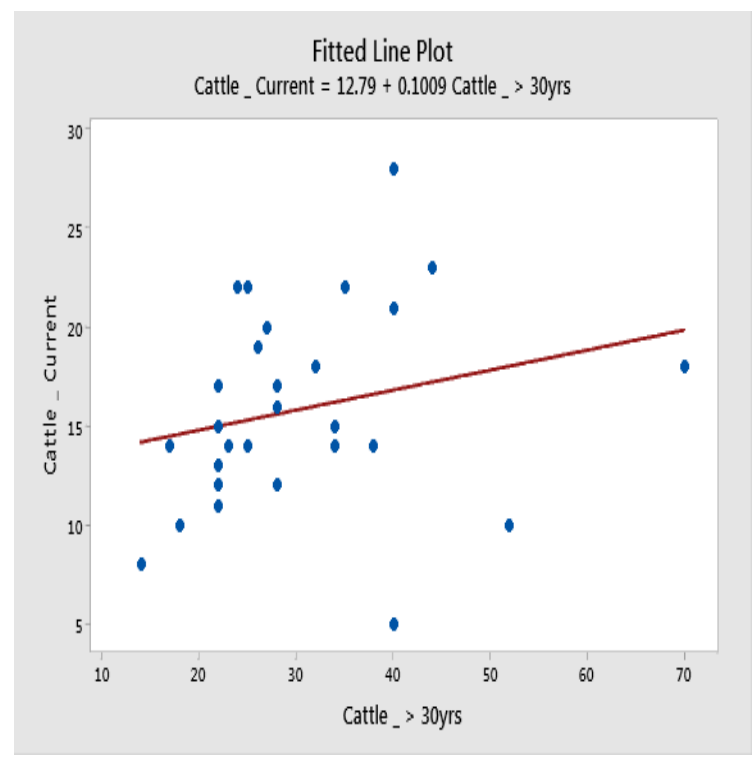

a

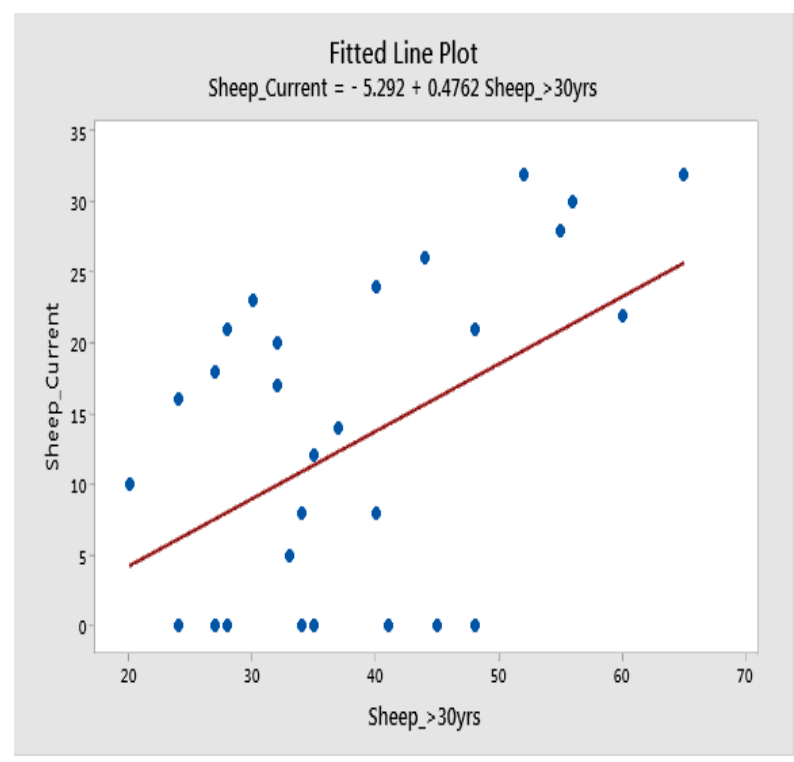

b

Figure 4. (a) Regression of Mean Cattle Population Trend ( $\mathrm{P}=0.215)$ and (b) Mean Sheep Population Trend $(\mathrm{P}=0.007)$ for Sabore study site

On the other hand, the mean populations of browser livestock (i.e., goat and camel) were highly increased with increasing bush encroachment coverage $(\mathrm{P}<0.05)$ in Kebena site than Sabore (Table 3).

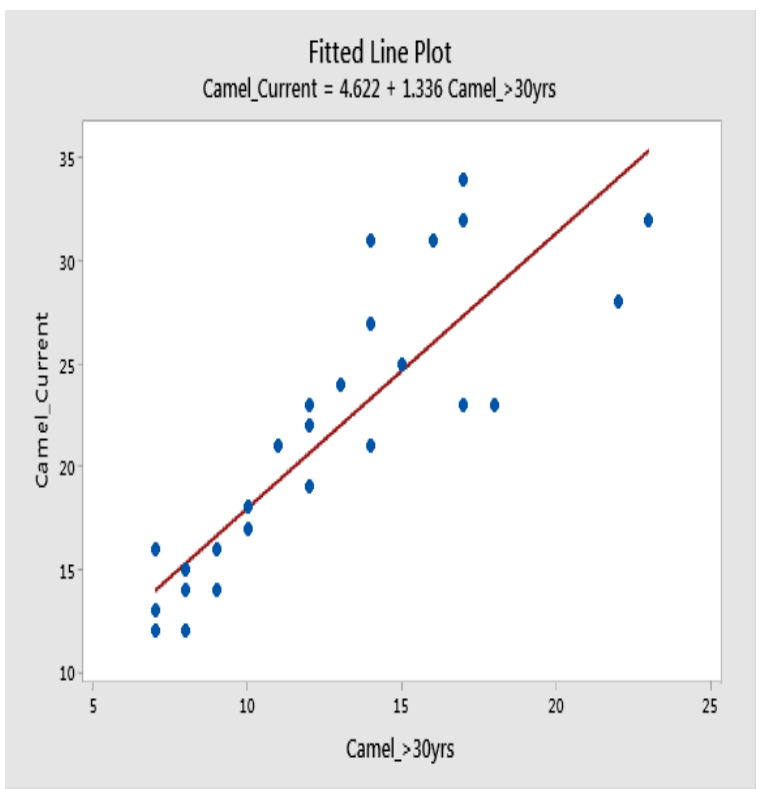

a

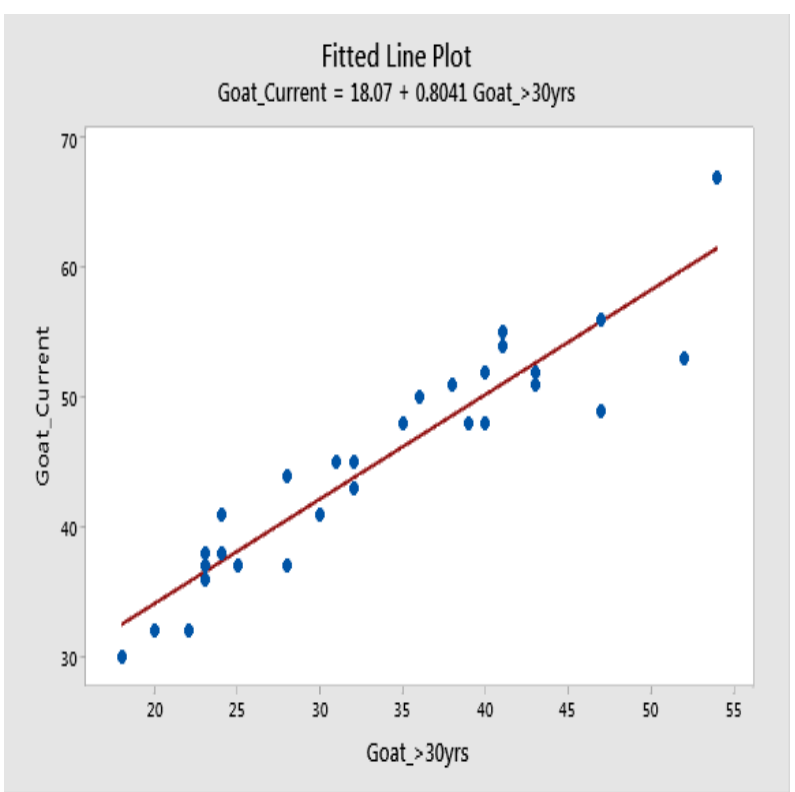

b

Figure 5. (a) Regression of Mean Camel Population Trend ( $\mathrm{P}=0.000$ ) and (b) Mean Goat Population Trend $(\mathrm{P}=0.000)$ for Kebena study site 
Moreover, the population of browser livestock was significantly associated with increasing coverage of bush encroachment at $(\mathrm{P}<0.05)$ (Figures 5).

\subsection{Relationship between Bush Coverage, Livestock Population and Productivity}

Figures 2 and 3 show pastoral household mean milk yield trends for high and low bush encroached sites, respectively. The result revealed that pastoral household milk yield was decreased for the last 30 years due to increasing bush encroachments'. But, the highest significant household milk yield reduction was observed for highly encroached sites (Figure 2). This is due to increasing rate of woody coverage for the last several years. This type of ecological shift makes a difficulty for the survival and productivity of a livestock. Similarly, the milk yield of cow decreased with increasing coverage of bush encroachment ( $\mathrm{P}>0.05)$ (Table 1). Accordingly, pastoral producers in all study sites perceived a decrease in milk yield of both cow and camel with increasing rate of bush coverage (Table 1). Similarly, grazer livestock population was decreased consecutively in the areas of high bush encroached sites, while the browser livestock population was pointed out to have increasing trend in the study district (Figures 5). Moreover, the trend of livestock population and their products (i.e. milk yield) was negatively associated to trend of increasing bush encroachment coverage.

\section{Discussion}

\subsection{Impact of Bush Encroachment on Milk Production Trend}

In line with this result, a comparative study conducted by Mugasi et al (2000) showed that livestock reared under relatively highly encroached grazing fields yielded less milk than less encroached fields. Similarly, Brigham et al (2015) reported that milk yield is directly related to the availability of feed and water. Shetie (2008) also mentioned that infestation of $P$. juliflora drastically declined the size of grazing and crop lands and finally decreased the quantity and quality of production. Anderson (2005) reported that the invasion of invasive alien plant species caused environmental, economic and social damage. On the other hand, Dubale (2008) also reported that exclusive subsequent feeding of Prosopis pods for an elongated period of time caused health problems to animals. Likewise, Nick et al (2012) indicated that excessive feeding of $P$. juliflora pod to livestock causes illness and death. Kohli et al (2004) reported that 50-60\% of the loss of native plant diversity and density was observed following infestation by A. conyzoides in northern part of India. Similarly, Alderman (1987) reported that poor smallholder dairy producers trade expensive calories (milk and meat) for the cheap calories (cereals), thereby, improving total food consumption.

\subsection{Impact of Bush Encroachment on Pastoral Livelihood}

In line to these results, Beruk and Tafesse (2000) reported that in most of the lowlands in Ethiopia, food security is highly associated to livestock and livestock products. Coppock (1994) reported that in the Borana plateau; roughly $40 \%$ of the gross revenue is obtained from milk and the remaining from live animals' sale. Correspondingly, Coppock (1994) reported that nearly all of the food and income for pastoralist is ultimately obtained from livestock. Despite their economic contribution, there has been a fundamental misunderstanding of the pastoral production system and the recent environmental challenges in Ethiopia like in many other countries in Africa. Due to that, currently bush encroachment was altering the economy of local people and national GDP at large.

\subsection{Impact of Bush Encroachment on Livestock Population Trend}

The results of current study indicated that there is a paradigm shift from grazer to browser (Figures 5). Similarly, many pastoral producers were aided by governmental and non-governmental organizations to support their livelihood, due to severe impacts of invasive species. This study is in line with Pasiecznik (1999) which reported that mesquite invasion forms impermeable, dense woods. The same source also stated that the invasion reduces grass cover of grazing lands and affects stocking density. Ward (2005) reported that bush encroachment reduces the carrying capacity for livestock. For example, according to Sheuyange, Oba, Weladji \& R. B. (2005) an approximately 26 million ha of woodland savannas in Namibia resulted in a loss of land productivity of as much as $100 \%$.

\subsection{Relationship between Bush Coverage, Livestock Population and Productivity}

In this study, the population of cattle and sheep were not significantly associated to the expansion of bush encroachment. On the other hand, goat and camel population has strong association with high expansion of woody species coverage. Moreover, camel is more selected by pastoral and agro-pastoral due to its higher milk production and market price than the milk of other livestock species. Similarly, Beruk and Tafesse (2000) indicated that the use of improved forage and supplementary feed by the pastoralists in the Afar region is insignificant, rather the primary feed sources of livestock in the region were the rangelands composed of 
indigenous plant species. For these reasons, feed shortage has become a serious problem for livestock herders in the study areas following highly expanding rate of bush encroachment. Similarly, Kamara, Swallow \& Kirk (2003) reported that a progressive growth of bush cover in dry savannah is responsible for decline in range condition in Southern Ethiopia. On the other hand, Amaha (2006) mentioned that a decline in pastoralists' income decreased in livestock production and livestock products as a result of decrease in rangeland vegetation. The same source also stated that pastoralists in Ethiopia are vulnerable to ecological instability and macro climatic variability. So, livestock production in pastoral areas is affected by range land degradation. Ethiopian Agricultural Research Organization [EARO] (2002) also reported that the lack of understanding of the relationship between the environment and pastoralists may also contribute to the misunderstanding of the pastoral production system and the priority needs of the pastoralists.

\section{Conclusions}

Bush Encroachment is a threat to livestock population and productivity particularly in Afar Region, eastern Ethiopia. The high expansion rate of woody coverage in the area, affects the livestock population and productivity. The results of current study indicated that there is a paradigm shift of pastoral livestock herding, from grazer to browser. Similarly, current study indicated that products obtained from livestock reared under relatively highly encroached grazing sites yielded less milk than less encroached sites. Currently, pastoral livestock producers perceived the impact of bush encroachment on livestock population and productivity, which includes shortage to animal feed and water. On the other hand, seasonal mobility, changing livestock species composition, searching for other source of household income and destocking are their adaptation strategies. Hence, the government and other stakeholders need to design early warning strategies for control and management of alarmingly increasing bush coverage, to save the environment and improve the livestock dependent community's adaptation in eastern Ethiopia.

\section{Acknowledgements}

We would like to thank the Haramaya University, especially Office of Postgraduate Studies and Collage of Agriculture for their support of materials and transport facilities at the period of field data collection. Thanks to Awash Fentale Districts' Pastoral and Agro-pastoral Office for providing secondary data. Our special gratitude also goes to the livestock herders and experts in the study areas, for their inimitable involvement during our study.

\section{Authors' contributions}

Sisay Kebede designed and conducted the study, analyzed and interpreted the results and written the manuscript. Tessema Zewdu, Mengistu Urge, Mehari Alebachew and Abule Ebro commenced the idea and edited the manuscript. All authors revised the manuscript and approved the final version.

\section{Competing interests}

The authors declare that they have no competing interests.

\section{References}

Abule, E., Snyman, H. A., Smit, G. N. (2005). Comparisons of pastoralists perceptions about rangeland resource utilisation in the Middle Awash Valley of Ethiopia. J Environ Manag, 75, 21-35. https://doi.org/10.1016/j.jenvman.2004.11.003

Alderman, H. (1987). Cooperative Dairy development in Karnataka, India: An assessment research report 64. IFPRI (International Food Research Institute), Washington, DC, USA. p. 60.

Amaha, K. (2006). Characterization of Rangeland Resources and Dynamics of the Pastoral Production Systems in the Somali Region of Eastern Ethiopia. PhD Thesis in the faculty of Natural and Agricultural Sciences Department of Animal, Wildlife and Grassland Sciences (Grassland Science) University of the Free State. Bloemfontein.

Andersson, S. (2005). Spread of the introduced tree species Prosopis juliflora (Sw.) C in the Lake Baringo area, Kenya.

Ayana, A., \& Oba, G. (2008). Herder perceptions on impacts of range enclosures, crop farming, fire ban and bush encroachment on the rangelands of Borana, southern Ethiopia. Human Ecology, 36, 201-215. https://doi.org/10.1007/s10745-007-9156-z

Beruk, Y., \& Tafesse, M. (2000). Pastoralism and agro-pastoralism: past and present. In: Pastoralism and agropastoralism, which way for ward? Proceeding of the 8th Annual conference of ESAP (Ethiopian 
Society of Animal Production). Addis Ababa Ethiopia. pp. 54-58.

Brigham, W., Forrest, D., Coppock, D. L., Bailey, D., \& Ward, A. (2015). Economic Analysis of Land and Livestock Management Interventions to Improve Resilience of a Pastoral Community in Southern Ethiopia. Journal of African Economics, 2015, 1-34.

Cecchi, G., Wint, W., Shaw, A., Marletta, A., Mattioli, R., \& Robinson, T. (2010). Geographic distribution and environmental characterization of livestock production systems in Eastern Africa. Agriculture, Ecosystems and Environment, 135(1-2), 98110. https://doi.org/10.1016/j.agee.2009.08.011

Coppock, D. L. (1994). The Boran Pleatue of Southern Ethiopia: Synthesis of Pastoral Research, Development and Change, 1980-91. ILCA systems study. No.5. ILCA, Addis Ababa, Ethiopia. pp. 393.

Dubale, A. (2008). Invasive Plants and Food Security: the case of Prosopis juliflora in the Afar region of Ethiopia.

Ethiopian Agricultural Research Organization (EARO). (2002). National Pastoral and Agro-Pastoral Strategic Research Planning document. Addis Ababa, Ethiopia.

Felker, P. (2008). Pers. comm. In F. Flintan (Ed.), Prosopis juliflora control and/ or utilization. Retrieved from http://doi.org/disasterriskreduction.net/fileadmin/user_upload/drought/docs/ELMT_Good_Practice_Bibliog raphy_Prosopisjuliflora[2].pdf

Gren, I.-M., Isacs, L., \& Carlsson, M. (2009). Costs of alien invasive species in Sweden. Ambio 2009, 38, 135-140. https://doi.org/10.1579/0044-7447-38.3.135

IFPRI and ILRI. (2000). Property Rights, Risk, and Livestock Development in Africa. N. McCarthy, B. Swallow, M. Kirk \& Peter Hazell, Eds. Washington, D.C.,International Food Policy Research Institute (IFPRI) and International Livestock Research Institute (ILRI). pp. 433.

IRIN. (2007). Africa: Can pastoralism survive in the 21st century? UN Integrated Regional Information Networks, World Press. Retrieved from http:// doi.org.worldpress.org/Africa/2861.cfm

Julia, R., Holland, D. W., \& Guenthner, J. (2007). Assessing the economic impact of invasive species: The case of yellow starthistle (Centaurea solsitialis L.) in the rangelands of Idaho, USA. Journal of Environmental Management, 85, 876-882. https://doi.org/10.1016/j.jenvman.2006.10.024

Kamara, A., Swallow, B., \& Kirk, M. (2003). Role of polices and development in pastoral resources management. The Borana rangeland in southern Ethiopia. Socio-economic and policy working paper, 53. International Livestock Research Institute (ILRI), Nairobi, Kenya.

Kohli, R. K., Dogra, K. S., Batish, D. R., \& Singh, H. P. (2004). Impact of invasive plants on the structure and composition of natural vegetation of north western Indian Himalayas. Weed Technology, 18, 1296-1300. https://doi.org/10.1614/0890-037X(2004)018[1296:IOIPOT]2.0.CO;2

Mugasi, S. K., Sabiit, E. N., Tayebwa, B. M. (2000). The economic implications of bush encroachment on livestock farming in rangelands of Uganda. African Journal of Range and Forage Science, 17, 64-69. https://doi.org/10.2989/10220110009485741

Mueller-mahn, D., Getachew, G., \& Rettberg, S. (2010). Pathways and dead ends of pastoral development among the Afar Karrayu in Ethiopia. European Journal for Development Research, 22, 660-677. https://doi.org/10.1057/ejdr.2010.37

Nick, M. P., Simon, K. C., Liz, J. T., \& Phil, J. C. H. (2012). Improving Food Security in Famine-prone Areas Using Invasive and Underutilized Prosopis Trees.

Nori, M., Switzer, J., \& Crawford, A. (2005). Herding on the Brink: Towards a Global Survey of Pastoral Communities and Conflict An Occasional Paper from the IUCN Commission on Environmental, Economic and Social Policy; Gland, Switzerland. Retrieved from http://doi.org/iisd/publications/pub.aspx?id=705

Pasiecznik, N. M. (1999). Prosopis-pest or providence, weed or wonder tree?. (Newsletter No. 28): European Tropical Forest Research Network.

Piguet, F. (2001). Even after good rains, Afar Pastoralists remain vulnerable. Report on Afar Region, UN-Emergencies Unit for Ethiopia, Addis Ababa.

Randolph, F., Schelling, E., Grace, D., Nicholson, F., Leroy, L., ... Ruel, M. (2007). Invited Review: Role of Livestock in Human Nutrition and Health for Poverty Reduction in Developing Countries. Journal of Animal Science, 85(11), 2788-2800. https://doi.org/10.2527/jas.2007-0467 
Ryan, F. (2011). US Forest Service Technical Assistance Trip to Ethiopia: Invasive Species Management: US Forest Service, cited in: Yibekal Abebe Tessema: Ecological and Economic Dimensions of the Paradoxical Invasive Species- Prosopis juliflora and Policy Challenges in Ethiopia. Journal of Economics and Sustainable Development, 3(8), 1-15.

Shetie, G. M. (2008). The Ecological Distribution and Socio-Economic Impacts of Prosopis juliflora (Sw.) DC. In the AmibaraWoreda, Afar National Region State. Addis Ababa, Ethiopia.

Sheuyange, A., Oba, G., \& Weladji, R. B. (2005). Effects of Anthropogenic Fire History on Savanna Vegetation in Northeastern Namibia. Journal of Environmental Management, 75, 189-198.

https://doi.org/10.1016/j.jenvman.2004.11.004

Ward, D. (2005). Do We Understand the Causes of Bush Encroachment in Africa Savannas?. Africa Journal Range and Forage Science, 22, 101-105. https://doi.org/10.2989/10220110509485867

\section{Copyrights}

Copyright for this article is retained by the author(s), with first publication rights granted to the journal.

This is an open-access article distributed under the terms and conditions of the Creative Commons Attribution license (http://creativecommons.org/licenses/by/3.0/). 